\title{
IL-12 superfamily members guiding the function of Roryt-dependent innate lymphocytes
}

\author{
Burkhard Becher \\ From 7th European Workshop on Immune-Mediated Inflammatory Diseases \\ Noordwijk aan Zee, the Netherlands. 28-30 November 2012
}

Most MHC class II expressing Ag-presenting cells (APCs) have the capacity to produce the cytokines IL-12 and IL-23 [1]. Both these heterodimeric pro-inflammatory cytokines share a common subunit (p40) which is covalently linked to p35 to form IL-12 and to p19 to form IL23. The biology of these two related cytokines is extremely divers. IL-12 is best known for its capacity to polarize $\mathrm{T}_{\mathrm{H}} 1$ cells and to activate NK and NKT cells. IL-12 is thus primarily involved in the initiation of cellular immune responses agains intracellular pathogens. The biology of IL-23 is much less understood, but it becomes increasingly clear that IL-23 can activate innate lymphocytes including a subclass of $\gamma \delta$ T cells [2] and Ror $\gamma t$-dependent innate lymphocytes (ILCs) [3]. IL-23 is further critical for the development of self-reactive pathogenic $\alpha \beta$ helper T cells in various models of autoimmune diseases [4].

In the context of anti-tumor immunity we discovered that IL-23 plays only a minor role in the development of anti-tumor responses. In fact, we found IL-23 to have primarily tumor-supportive properties. In contrast, IL-12 has clearly a potent tumor-suppressive properties. Surprisingly, we identified a Roryt-dependent IL-12R bearing ILC homing into the microenvironment of skin tumors [5]. These ILCs upon sensing IL-12 are able to mount a potent innate response in the tumor-microenvironment, leading to alterations in tumor microvessels and the formation of a pro-inflammatory myeloid cell response. Taken together, our initial understanding of IL-12 and IL-23 biology was restricted to adaptive $\mathrm{T}$ cells. The impact of these cytokines on $\gamma \delta$ T cells and ILCs is only now being discovered.

Published: 28 November 2012

\section{References}

1. Gutcher I, Becher B: APC-derived cytokines and T cell polarization in autoimmune inflammation. J.Cin. Invest 2007, 117:1119-1127.

Institute of Experimental Immunology, University of Zurich, Switzerland
2. Pantelyushin S, Haak S, Ingold B, Kulig P, Heppner FL, Navarini AA, Becher B: Rorgammat+ innate lymphocytes and gammadelta $T$ cells initiate psoriasiform plaque formation in mice. J.Cin. Invest 2012, 122:2252-2256.

3. Vonarbourg C, Mortha A, Bui VL, Hernandez PP, Kiss EA, Hoyler T, Flach M, et al: Regulated expression of nuclear receptor RORyt confers distinct functional fates to NK cell receptor-expressing RORyt(+) innate lymphocytes. Immunity 2010, 33:736-751.

4. Croxford AL, Mair F, Becher B: IL-23: One cytokine in control of autoimmunity. Eur. J. Immunol 2012, 42:2263-2273.

5. Eisenring $M$, vom Berg J, Kristiansen G, Saller E, Becher B: IL-12 initiates tumor rejection via lymphoid tissue-inducer cells bearing the natural cytotoxicity receptor NKp46. Nat Immunol 2010, 11:1030-1038.

doi:10.1186/1479-5876-10-S3-I15

Cite this article as: Becher: IL-12 superfamily members guiding the function of Roryt-dependent innate lymphocytes. Journal of Translational Medicine 2012 10(Suppl 3):115.
Submit your next manuscript to BioMed Central and take full advantage of:

- Convenient online submission

- Thorough peer review

- No space constraints or color figure charges

- Immediate publication on acceptance

- Inclusion in PubMed, CAS, Scopus and Google Scholar

- Research which is freely available for redistribution
() Bïomed Central 